\title{
Prototipe Manajemen Bandwidth pada Jaringan Internet Hotel Harvani dengan Mikrotik RB 750r2
}

\author{
Aan Restu Mukti ${ }^{\left.{ }^{*}\right)}$, Rahmat Novrianda Dasmen ${ }^{2}$ \\ ${ }^{1}$ Program Studi Teknik Informatika, Fakultas Ilmu Komputer, Universitas Bina Darma, Palembang \\ ${ }^{2}$ Program Studi Teknik Komputer, Fakultas Vokasi, Universitas Bina Darma, Palembang \\ ${ }^{1,2}$ Jln. Jenderal A. Yani No. 03, Kota Palembang, 30264, Indonesia \\ email: ${ }^{1}$ aanrestu@binadarma.ac.id, ${ }^{2}$ rahmat.novrianda.d@gmail.com \\ Copyright (C2019, Politeknik Harapan Bersama, Tegal
}

\begin{abstract}
Harvani Hotel has 5 (five) floors, where each floor has 1 (one) Access Point (AP). All Access Points, servers and several Personal Computers (PCs) are connected to the RB 750r2 microtic router which is connected directly to the Internet Service Provider (ISP) so that all users are connected to the internet network. The problem that occurs is the uneven distribution of bandwidth so that the first user connected to the internet will get more bandwidth with the highest internet access speed. This causes interference to other users who feel the speed of internet access is very slow, which results in user inconvenience in using internet access. Therefore, bandwidth management is done in this research uses the action research method, where the prototype is focused on 5 Access Points by using ISP that provide bandwidth services of $2.5 \mathrm{Mbps}$ and shared equally among 5 Access Points. From the testing results using the speedtest known that every AP only get the throughput between $100-400 \mathrm{kbps}$. This is providing that the bandwidth used of every AP does not expand $512 \mathrm{kbps}$ and the bandwidth distribution of every AP has been ordered to remove the existence of user interest.
\end{abstract}

Abstrak - Hotel Harvani memiliki 5 (lima) lantai, dimana setiap lantai memiliki masing-masing 1 (satu) Access Point (AP). Seluruh Access Point, server dan beberapa Personal Computer (PC) terhubung dengan router mikrotik RB 750r2 yang terkoneksi langsung dengan Internet Service Provider (ISP) sehingga keseluruhan user terhubung dalam jaringan internet. Permasalahan yang terjadi adalah pembagian bandwidth yang tidak merata sehingga user yang pertama terkoneksi internet akan memperoleh bandwidth lebih besar dengan kecepatan akses internetnya juga paling besar. Hal ini menyebabkan gangguan terhadap user lainnya yang merasakan kecepatan akses internet yang sangat lambat sehingga berdampak kepada ketidaknyamanan user dalam menggunakan akses internet. Oleh karena itu, pada penelitian ini dilakukan manajemen bandwidth dengan menggunakan metode action research, dimana prototipe difokuskan pada 5 Access Point dengan menggunakan ISP yang memberikan layanan bandwidth sebesar 2,5 Mbps serta dibagi secara merata kepada 5 Access Point. Dari hasil pengujian menggunakan speedtest diketahui bahwa setiap AP hanya memperoleh throughput antara 100 400 kbps. Hal ini membuktikan bahwa penggunaan bandwidth setiap AP tidak melebihi 512 kbps dan pembagian bandwidth setiap AP telah merata sehingga menghilangkan adanya gangguan antar user.

Kata Kunci - access point (AP), RB 750r2, ISP, bandwidth, action research

*) penulis korespondensi: Aan Restu Mukti

Email: aanrestu@binadarma.ac.id

\section{PENDAHULUAN}

Hotel Harvani merupakan objek yang dipilih pada penelitian ini yang memiliki 5 (lima) lantai. Hotel ini telah memiliki jaringan komputer dimana terdiri dari beberapa perangkat komputer yaitu server, beberapa Personal Computer (PC) dan 5 (lima) Access Point (AP) yang dipasangkan masing-masing 1 AP pada setiap lantai Hotel Harvani. "AP merupakan suatu perangkat jaringan yang berisi sebuah transceiver dan antena untuk transmisi dan menerima sinyal ke dan dari clients remote" [1]. "AP berfungsi sebagai pengatur lalu lintas daya, maka memungkinkan banyak client yang dapat saling terhubung melalui network" [2]. Seluruh perangkat komputer ini terhubung dengan router mikrotik RB 750r2 yang terkoneksi dengan Internet Service Provider (ISP) sehingga keseluruhan jaringan komputer Hotel Harvani terhubung dengan internet. Akan tetapi, terjadi permasalahan pada jaringan internet Hotel Harvani yaitu pembagian bandwidth kepada setiap user yang tidak merata. "Bandwidth merupakan suatu ukuran rentang frekuensi maksimum yang dapat mengalirkan data dari suatu tempat ke tempat lain dalam suatu waktu tertentu" [3]. Hal ini menyebabkan hanya user yang pertama kali terhubung jaringan internet yang memperoleh bandwidth yang besar serta merasakan kecepatan akses internet yang cukup tinggi. Disisi lain hal ini memberi dampak ketidaknyamanan terhadap user lainnya dalam mengakses jaringan internet, karena user yang lain memperoleh bandwidth yang jauh lebih kecil sehingga kecepatan akses internet-nya juga lambat.

Oleh karena itu, pada penelitian yang menggunakan metode peneltian action research ini dilakukan manajemen bandwidth pada jaringan internet Hotel Harvani sehingga bandwidth dapat dibagi secara merata untuk setiap user. Pada penelitian ini digunakan prototipe, dimana prototipe hanya difokuskan untuk pembagian bandwidth kepada 5 (lima) Access Point yang terdapat pada Hotel Harvani. Selain itu, untuk koneksi terhadap jaringan internet dipergunakan modem yang telah memiliki Internet Service Provider (ISP) serta terhubung kepada router mikrotik RB 750r2, dimana ISP memberikan layanan bandwidth sebesar 2,5 Mbps. Layanan bandwidth ini akan dibagi masing-masing sebesar 512 Kbps untuk setiap AP, dimana konfigurasi manajemen bandwidth menggunakan program winbox yang menggunakan "Graphical User Interface (GUI) sehingga memberikan kemudahan dalam proses konfigurasi manajemen bandwidth 
pada router mikrotik" [4]. Dan untuk pengujian throughput yang diterima oleh user (AP) menggunakan internet speed test. "Throughput merupakan jumlah data per satuan waktu yang dikirim untuk suatu terminal tertentu di dalam sebuah jaringan, dari satu titik jaringan, atau dari satu titik ke titik jaringan yang lain" [5].

\section{PENELITIAN YANG TERKAIT}

Penelitian yang telah dilakukan oleh peneliti terdahulu memanfaatkan berbagai macam metode untuk dapat melakukan konfigurasi manajemen bandwidth, berikut ini beberapa penelitian yang menggunakan metode manajemen bandwidth yang berbeda-beda: "Perancangan Manajemen Bandwidth Inter mengunakan Metode Fuzzy Sugeno" [3], "Manajemen Bandwidth dengan metode HTB (Hierarchical Token Bucket) pada Sekolah Menengah Pertama Negeri 5 Semarang" [6], "Bandwidth Manajemen Queue Tree Vs Simple Queue" [7], "Management Bandwidth pada Dynamic Queue menggunakan Metode Per Connection Queuing" [8] dan "Manajemen Jaringan Internet Sekolah menggunakan Router Mikrotik dan Proxy Server" [9]. Merujuk pada peneliti terdahulu, maka penelitian saat ini dilakukan dengan metode penelitian action research dengan menerapkan metode manajemen bandwidth simple queue.

Selain itu, penelitian yang terdahulu juga memiliki tujuan dan manfaat dalam manajemen bandwidth yang berbeda-beda baik untuk analisa Quality of Service (QOS), peningkatan QOS, penstabilan koneksi internet hingga mencegah penurunan performansi jaringan internet, diantaranya: "Manajemen Bandwidth Jaringan Hotspot berbasis Mikrotik Router" [10], "Penerapan Quality of Service pada Jaringan Internet menggunakan Metode Hierarchical Token Bucket" [11], "Analisa Management Bandwidth dengan Metode Antrian Hirarchical Token Bucket" [12] dan "Analisis Management Bandwidth menggunakan Metode Per Connection Queue (PCQ) dengan Authentikasi RADIUS" [13]. Pada penelitian ini, manajemen bandwidth bertujuan untuk memberikan bandwidth kepada 5 AP secara merata dan sama besar yaitu sebesar $512 \mathrm{Kbps}$ untuk setiap AP.

\section{A. Action Research}

\section{METODE PENELITIAN}

Proses penelitian ini menggunakan metode penelitian "Action Research yang merupakan salah satu bentuk rancangan penelitian" [14]. "Di dalam metode penelitian action research, peneliti dapat mendeskripsikan, menginterpretasi dan menjelaskan suatu kondisi sosial pada saat yang bersamaan dengan melakukan intervensi yang bertujuan untuk perbaikan atau partisipasi" [15]. Berikut merupakan gambar dan tahapan dari metode penelitian action research, yaitu :

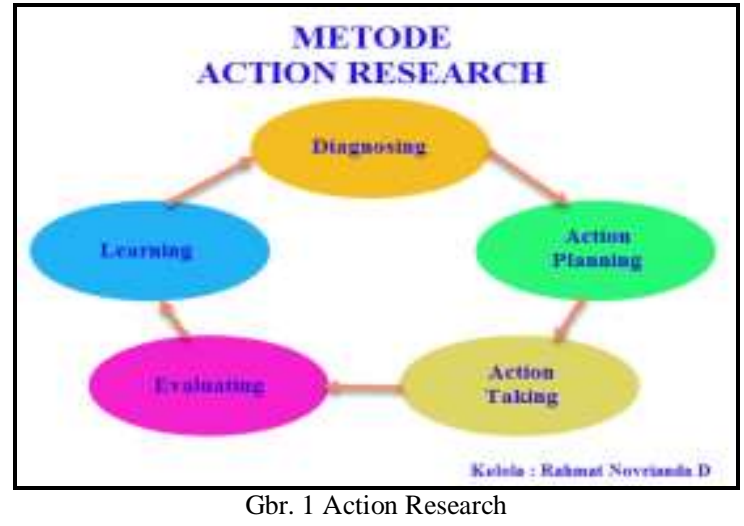

- diagnosing (Melakukan diagnosa)

- action planning (Membuat rencana tindakan)

- action taking (Melakukan tindakan)

- evaluating (Melakukan evaluasi)

- learning (Pembelajaran)

\section{HASIL DAN PEMBAHASAN}

\section{A. Diagnosing}

Melakukan diagnosa dapat dimulai dari topologi jaringan yang digunakan pada Hotel Harvani, dimana terdapat 1 (satu) server, 5 (lima) Access Point, 1 (satu) Switch, 1 (satu) Router mikrotik RB 750r2, 5 (lima) Personal Computer dan Internet Service Provider (ISP) yang dapat dilihat pada gbr. 1 di bawah ini. Permasalahan yang terjadi adalah pembagian bandwidth yang tidak sama rata pada Hotel Harvani, maka perlu dilakukan manajemen bandwidth dengan prototipe difokuskan untuk pembagian bandwidth secara merata kepada 5 AP yang terdapat pada Hotel Harvani.

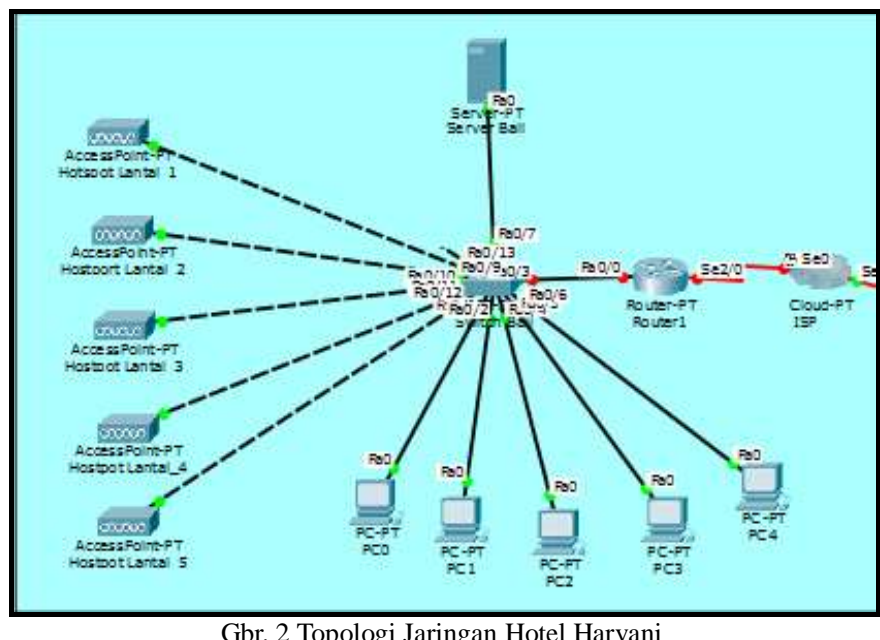

\section{B. Action Planning}

Dari permasalahan yang terjadi pada Hotel Harvani, maka rencana tindakan yang diambil adalah melakukan konfigurasi manajemen bandwidth dengan metode simple queue pada router mikrotik RB 750r2. Bandwidth yang diberikan oleh ISP adalah sebesar 2,5 Mbps (menggunakan modem USB yang dilengkapi dengan SIM card salah satu provider), dapat dilihat pada gbr. 3 dibawah ini melalui pengujian bandwidth dengan bantuan internet speed test diperoleh bandwidth ISP adalah sebesar 2,83 Mbps. Bandwidth ini akan dibagi kepada 5 AP dengan bandwidth sebesar $512 \mathrm{Kbps}$ untuk masing- 
masing AP

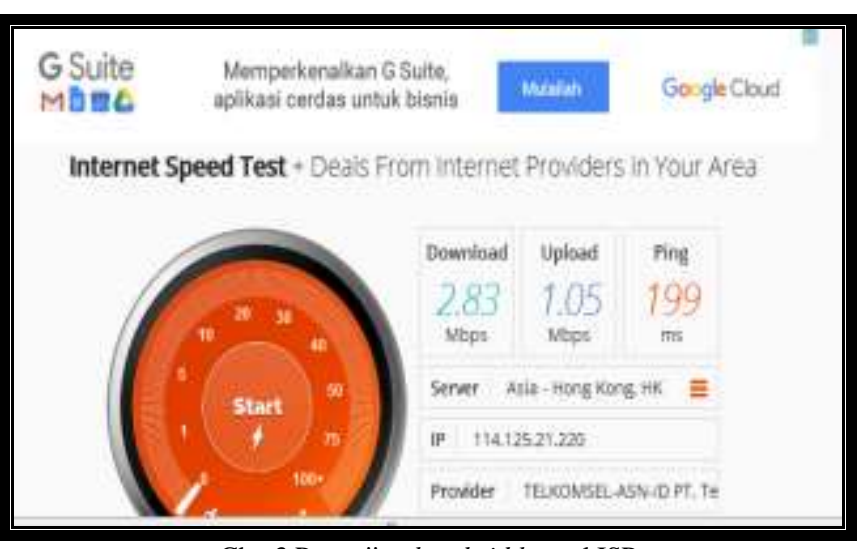

Gbr. 3 Pengujian bandwidth awal ISP

\section{Action Taking}

Setelah dilakukan pembuatan rencana tindakan, maka tahap proses penelitian berikutnya adalah melakukan tindakan sesuai dengan perencanaan tersebut. Berikut ini dapat dilihat dari gbr. 4 hingga gbr. 12 merupakan tahapan konfigurasi manajemen bandwidth pada program winbox. Dimana proses konfigurasi tersebut dimulai dari login program winbox, melakukan koneksi modem yang telah dilengkapi dengan ISP, melakukan pengujian koneksi internet, konfigurasi IP address, DNS, NAT hingga setting IP client. Kemudian tahapan akhir adalah melakukan pembagian bandwidth dengan menerapkan metode simple quеие pada program winbox. Berikut ini hasil tindakan yang dilakukan pada penelitian ini seperti pada Gbr.4, Gbr. 5, Gbr.6, Gbr.7, Gbr.8, Gbr.9, Gbr.10, Gbr.11, dan Gbr.12.

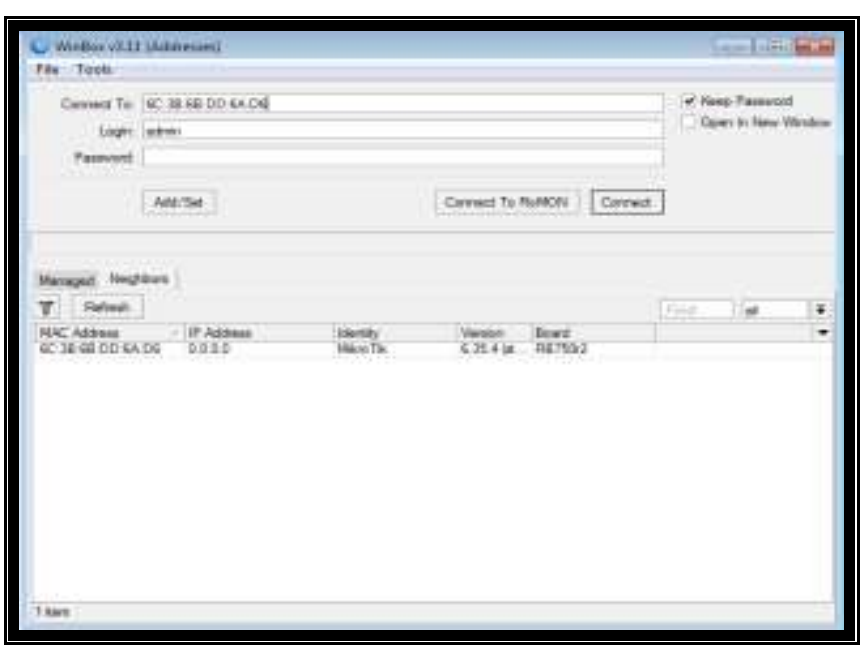

Gbr. 4 Login Program Winbox

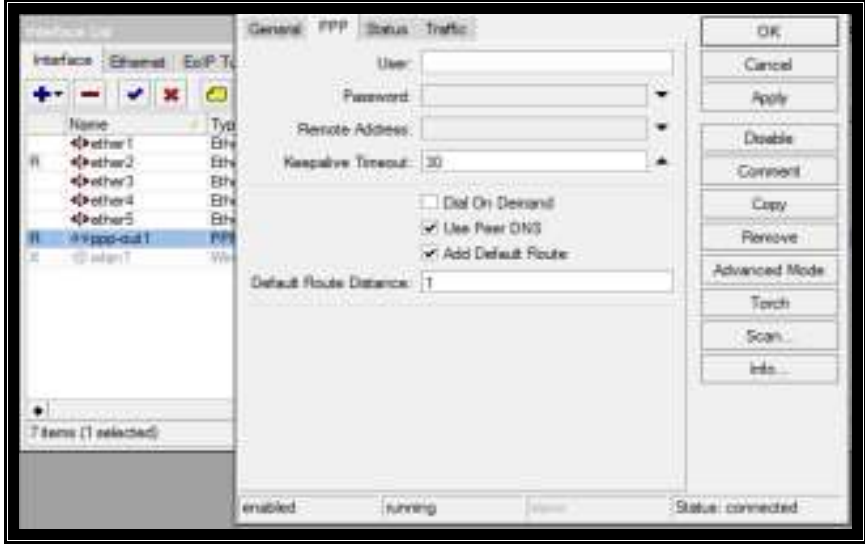

Gbr. 5 Melakukan Koneksi Modem

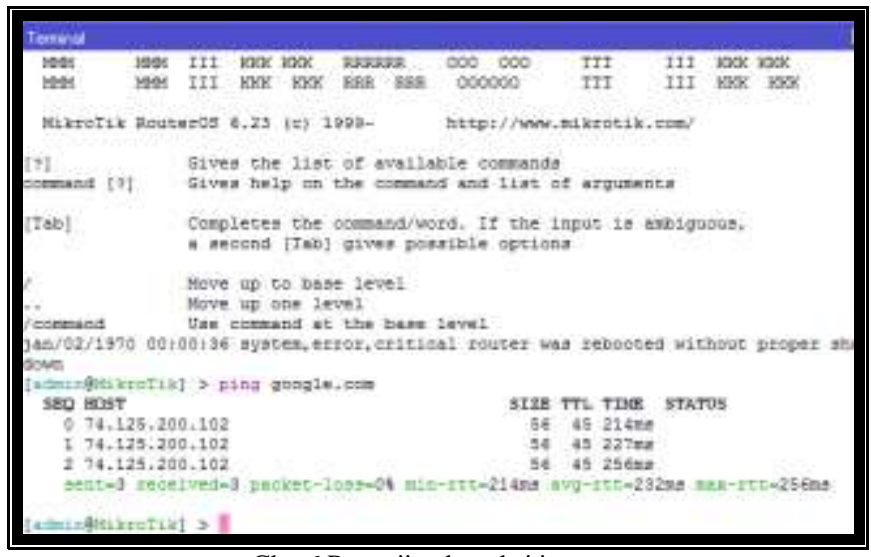

Gbr. 6 Pengujian koneksi internet

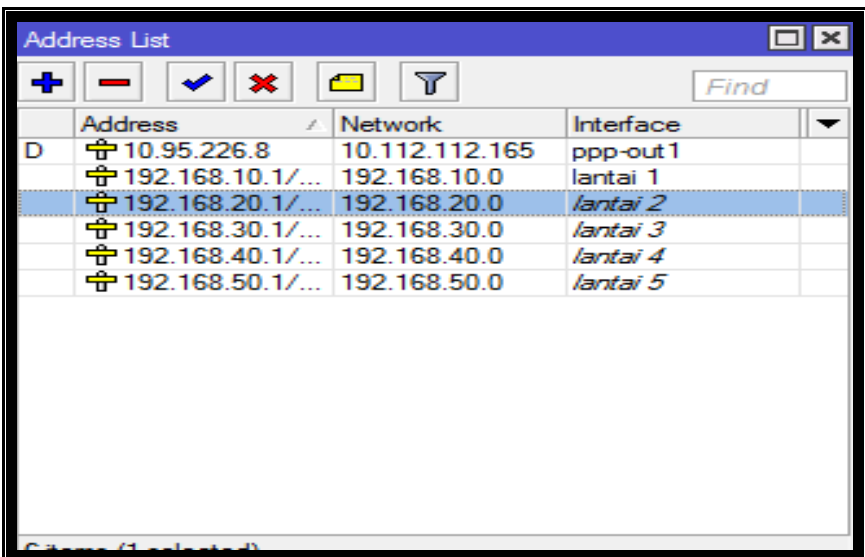

Gbr. 7 Konfigurasi IP Address

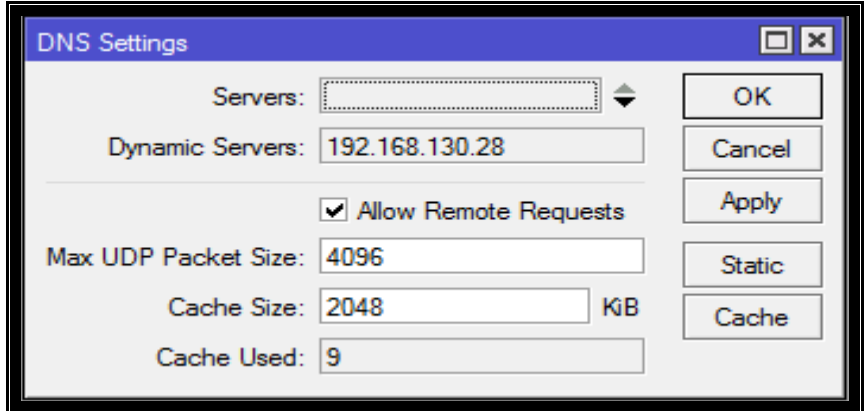

Gbr.8 Konfigurasi DNS 


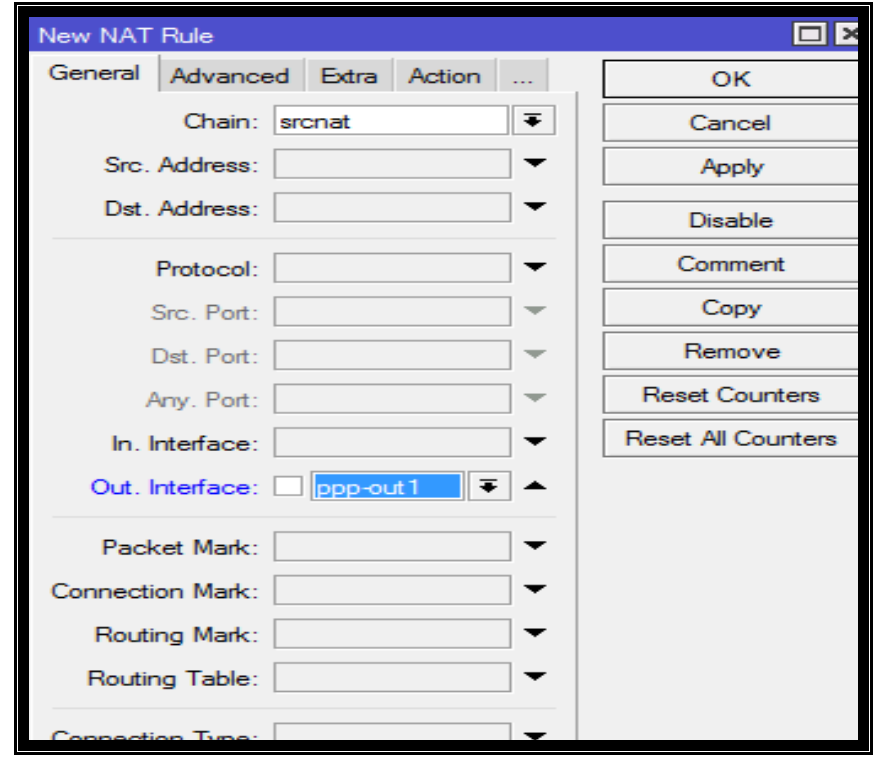

Gbr. 9 Setting Out Interface (NAT)

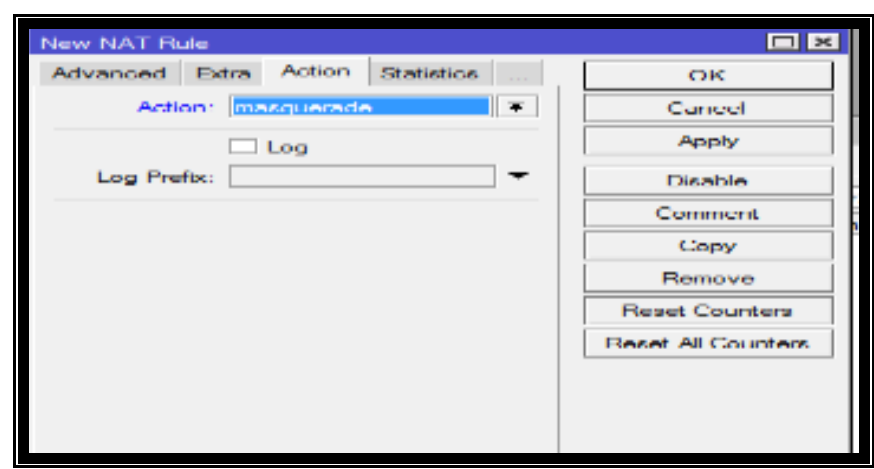

Gbr. 10 Setting Action (NAT)

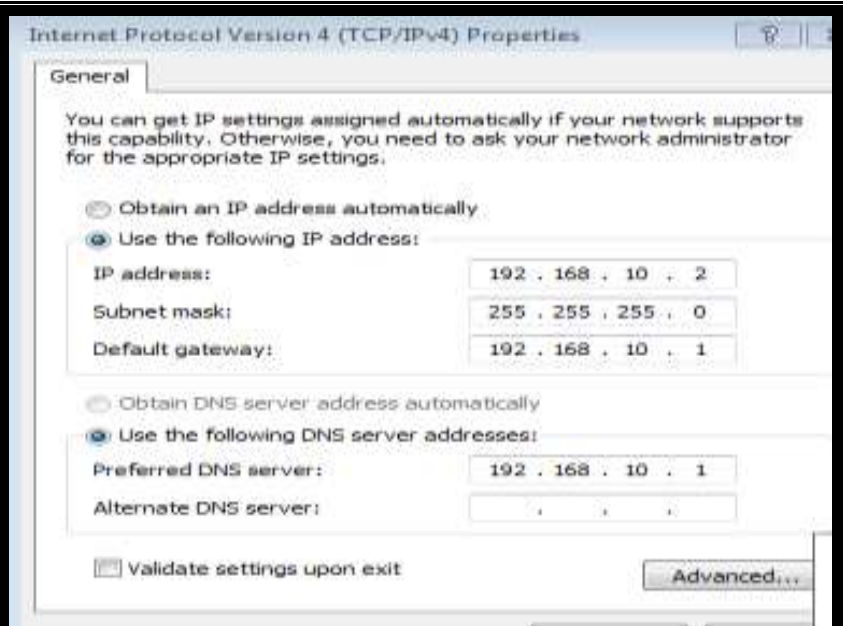

Gbr. 11 Setting IP Client

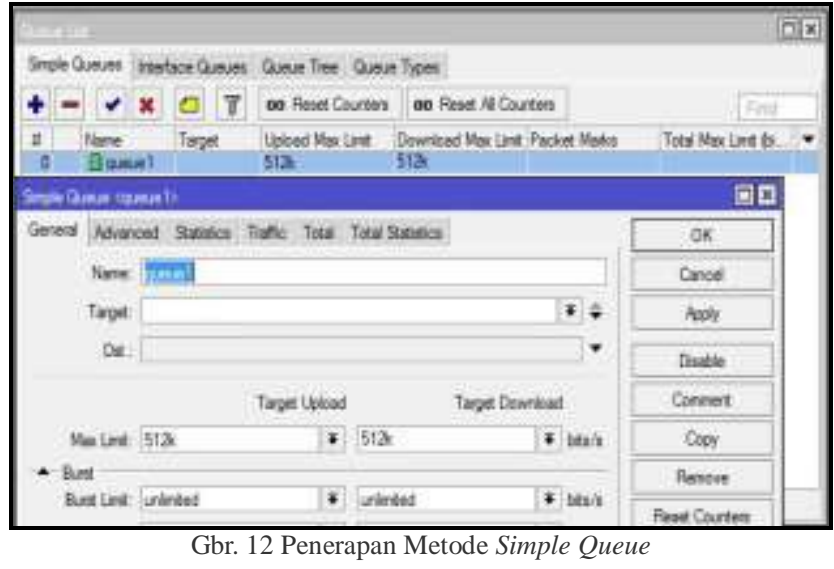

Setelah dilakukan konfigurasi manajemen bandwidth secara benar dan tepat pada program winbox dengan menggunakan metode simple quеие, maka dapat dilihat pada gbr. 13 di bawah ini bahwa setiap AP yang berada pada setiap lantai Hotel Harvani diberikan batasan bandwidth maksimum sebesar 512 Kbps untuk AP dari lantai 1 hingga lantai 5 Hotel Harvani, sperti pada Gbr.13.

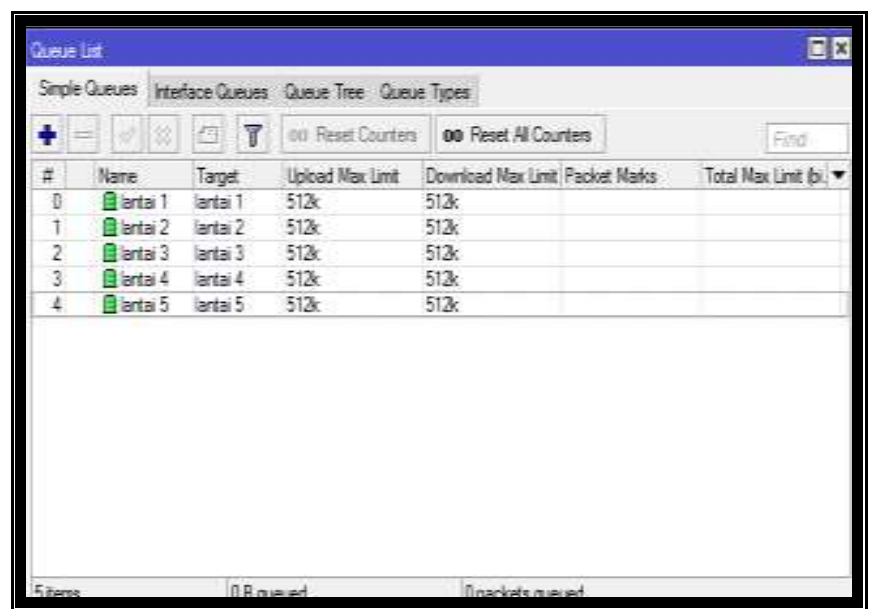

Gbr. 13 Hasil manajemen bandwidth dengan metode simple queue

\section{Evaluating}

Pada tahapan ini, peneliti melakukan pengujian terhadap hasil konfigurasi manajemen bandwidth yang telah dilakukan sebelumnya, dimana dalam pengujian bandwidth yang diterima user (atau disebut dengan throughput) dengan bantuan internet speed test. Berikut ini pada Gbr. 14, Gbr.15, Gbr.16, Gbr.17, dan Gbr. 18 dapat dilihat hasil pengujian throughput yang diterima user dari AP pada lantai 1 hingga lantai 5 Hotel Harvani. 


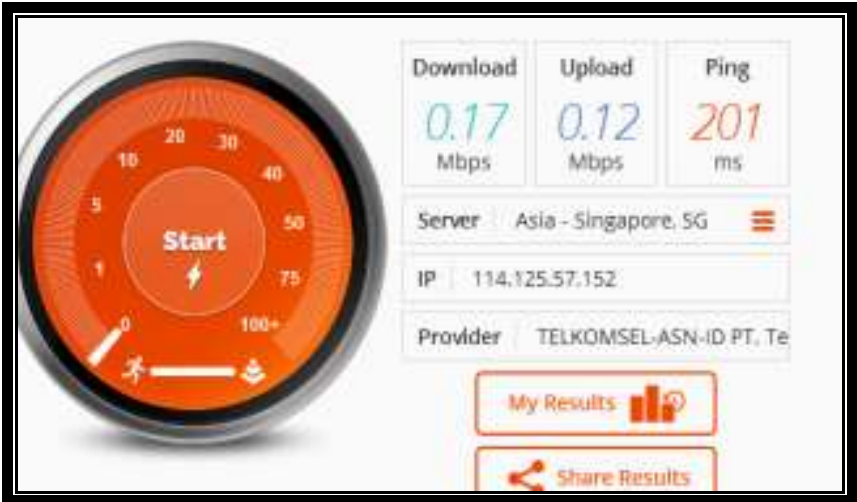

Gbr. 14 Pengujian througput Lantai 1

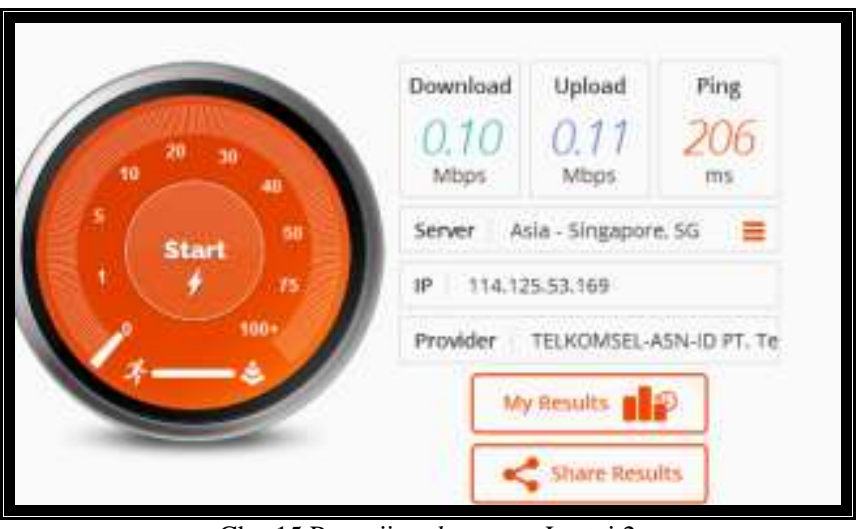

Gbr. 15 Pengujian througput Lantai 2

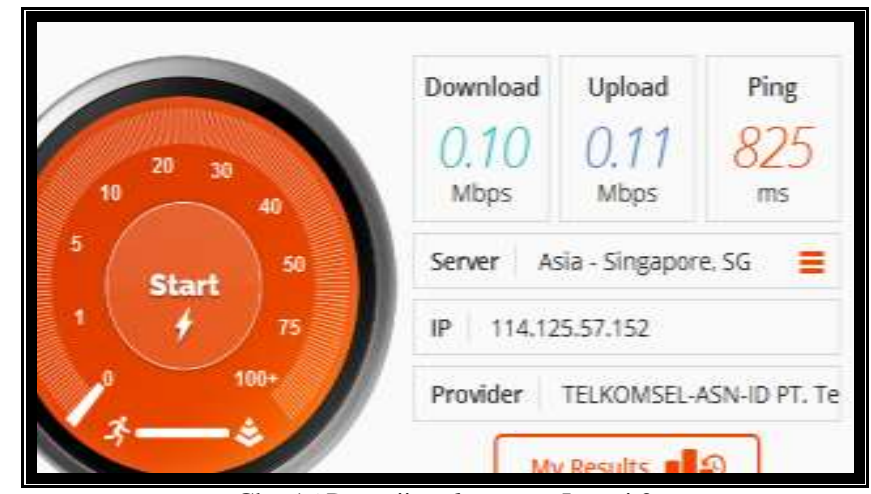

Gbr. 16 Pengujian througput Lantai 3

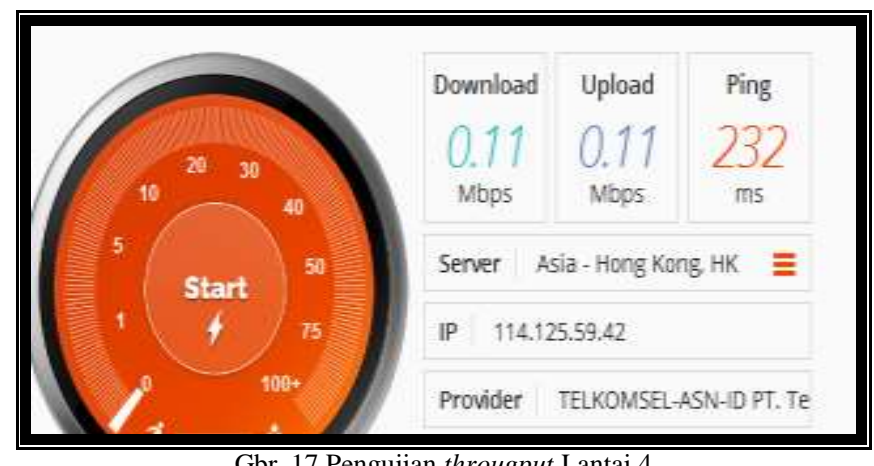

Gbr. 17 Pengujian througput Lantai 4

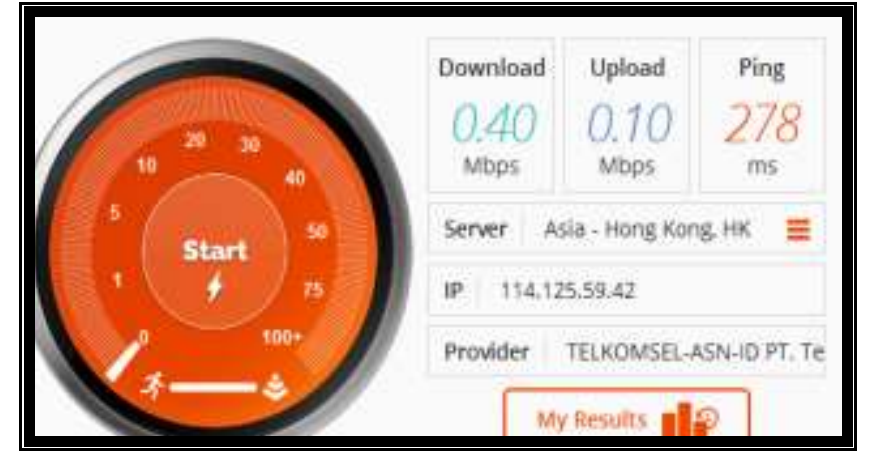

Gbr. 18 Pengujian througput Lantai 5

Dari hasil pengujian diatas dapat dilihat bahwa througput yang diterima pada lantai 1 sebesar $170 \mathrm{Kbps}$, throughput lantai 2 dan 3 sebesar $100 \mathrm{Kbps}$, throughput pada lantai 4 sebesar $110 \mathrm{Kbps}$ dan throughput yang diterima user pada lantai 5 adalah sebesar 400 Kbps. Dari penjelasan tersebut, dapat diketahui bahwa throughput yang diterima oleh user pada setiap lantainya tidak melebihi 512 Kbps yang merupakan batasan bandwidth maksimum pada setiap lantai setelah dilakukan manajemen bandwidth dengan metode simple queue. Hal ini membuktikan bahwa konfigurasi manajemen bandwidth telah berhasil dan tepat sesuai dengan perencanaan.

\section{E. Learning}

Pembelajaran yang diperoleh dari penelitian ini adalah mengetahui dan memahami proses konfigurasi manajemen bandwidth dengan mengimplementasikan metode simple queue. Manajemen bandwidth sangat bermanfaat dalam pembagian bandwidth secara merata untuk user sehingga user dapat mengakses jaringan internet pada Hotel Harvani dengan hak guna bandwidth yang sama. Pada penelitian ini, hanya digunakan prototipe dengan bandwidth ISP sebesar 2,5 Mbps yang dibagi secara merata sebesar 512 kbps untuk setiap AP. Oleh karena itu, dari hasil prototipe yang telah dilakukan dapat menjadi pertimbangan bahkan pedoman dalam implementasi terhadap manajemen bandwidth ISP yang sebenarnya dimiliki oleh Hotel Harvani serta dapat meningkatkan kualitas pelayanan penggunaan akses internet untuk user.

\section{KESIMPULAN}

Dari hasil penelitian yang dilakukan, maka dapat ditarik beberapa kesimpulan, penelitian ini menggunakan prototipe dengan bandwidth ISP kurang lebih sebesar 2,5 Mbps serta memanfaatkan router mikrotik RB 750r2 dan 5 Access Point yang dimiliki Hotel Harvani. Manajemen bandwidth yang dilakukan menggunakan metode simple queue yang dikonfigurasikan melalui program winbox, dimana diatur sehingga setiap Access Point hanya memperoleh bandwidth maksimal 512 kbps. Berdasarkan hasil pengujian menggunakan speedtest setiap AP hanya memperoleh throughput antara 100 - $400 \mathrm{kbps}$, yang berarti tidak melebihi batas bandwidth maksimal yaitu 512 kbps. Pembatasan penggunaan maksimal bandwidth terhadap setiap AP ini dapat menghilangkan gangguan jaringan internet antara user, karena setiap user memperoleh hak guna jaringan internet yang sama. 


\section{UCAPAN TERIMA KASIH}

Kami ucapkan terima kasih kepada pihak yang telah memberikan kami izin dalam penggunaan perangkat keras yang dibutuhkan serta kami juga mengucapkan terima kasih kepada beberapa mahasiswa Universitas Bina Darma yang juga berpartisipasi dalam pengumpulan data yang kami butuhkan dalam penyelesaian penelitian ini.

\section{DAFTAR PUSTAKA}

[1] R. N. Dasmen, "Implementasi Raspberry Pi 3 sebagai Wireless Access Point pada STIPER Sriwigama Palembang," J. Inform. J. Pengemb. $I T$, vol. 3, no. 3, pp. 387-393, 2018.

[2] and S. W. M. Limantara, Arthur Daniel, Agata Iwan Candra, "Manajemen Data Lalu Lintas Kendaraan Berbasis Sistem Internet Cerdas Ujicoba Implementasi Di Laboratorium Universitas Kadiri," in Prosiding Semnastek, 2017.

[3] M. Rofiq, "Perancangan Manajemen Bandwidth Inter Menggunakan Metode Fuzzy Sugeno," J. Ilm. Teknol. Inf. Asia, vol. 7, no. 1, pp. 115, 2013.

[4] R. N. Dasmen, "Implementasi Authentication Captive Portal pada Wireless Local Area Network PT. Rikku Mitra Sriwijaya," Regist. J. Ilm. Teknol. Sist. Inf., vol. 4, no. 2, pp. 67-80, 2018.

[5] R. F. Aswariza, D. Perdana, and R. M. Negara, "Analisis Throughput Dan Skalabilitas Virtualized Network Function VyOS Pada Hypervisor VMWare ESXi, XEN dan KVM," J. INFOTEL (Informatika - Telekomun. - Elektron., vol. 9, no. 1, pp. 70-74, 2017.

[6] A. I. Wijaya, L. B. H. Handoko, and M. Kom, "Manajemen Bandwidth Dengan Metode HTB (Hierarchical Token Bucket) Pada Sekolah
Menengah Pertama Negeri 5 Semarang," J. Tek. Inform. Univ. Dian Nuswantoro Semarang, Indones., 2013.

[7] E. Darmawan, I. Purnama, T. I. R. Mahardika, and I. W. S. Wicaksana "Bandwidth Manajemen Queue Tree vs Simple Queue," in Konferensi Nasional Sistem Informasi 2012, 2012.

[8] B. Rifai, "Management Bandwidth Pada Dynamic Queue Menggunakan Metode Per Connection Queuing," J. Ilmu Pengetah. dan Teknol. Komput., vol. 2, no. 2, pp. 73-79, 2017.

[9] Purwanto, Kusrini, and R. R. Huizen, "Manajemen Jaringan Internet Sekolah Menggunakan Router Mikrotik Dan Proxy Server," J. Teknol. Inf. Respati, vol. 11, no. 32, 2016

[10] F. Ardianto and M. Rosyidah, "Manajemen Bandwidth Jaringan Hotspot Berbasis Mikrotik Router," in Seminar Nasional Penelitian dan Pengabdian Masyarakat AVoER 9, 2017.

[11] C. P. Antodi, A. B. Prasetijo, and E. D. Widianto, "Penerapan Quality of Service Pada Jaringan Internet Menggunakan Metode Hierarchical Token Bucket," J. Teknol. dan Sist. Komput., vol. 5, no. 1, pp. 23-28, 2017.

[12] E. Manalu, D. Arisandi, and S. Sukri, "Analisa Management Bandwidth Dengan Metode Antrian Hirarchical Token Bucket," in Prosiding CELSciTech 2, 2017, p. tech_10-tech_17.

[13] A. Syukur, "Analisis Management Bandwidth Menggunakan Metode Per Connection Queue (PCQ) dengan Authentikasi RADIUS," IT $J$. Res. Dev., vol. 2, no. 2, pp. 78-89, 2018.

[14] Kurniati and R. N. Dasmen, "The Simulation of Access Control List (ACLs) Network Security for Frame Relay Network at PT. KAI Palembang," Lontar Komput. J. Ilm. Teknol. Inf., vol. 10, no. 1, pp. 49-61, 2019.

[15] R. N. Dasmen and Rasmila, "Implementasi Raspberry Pi 3 pada Sistem Pengontrol Lampu berbasis Raspbian Jessie," JEPIN (Jurnal Edukasi dan Penelit. Inform., vol. 5, no. 1, pp. 46-53, 2019. 